\title{
THE POWER OF TRANSNATIONAL PROJECTS
}

\author{
Barbara Cvjetan \\ Faculty of Organisational Sciences, University of Belgrade, Serbia
}

\begin{abstract}
The process of globalization has put organizations in the position of facing daily challenges in a dynamic and complex environment. Each organization strives to respond to market demands and maintain competitiveness in its field of business in the best possible way, which has led to the popularization of the use of project management in a wide variety of areas. This paper provides insight into the functioning of transnational projects which represent inseparable part of a transnational program. It gives an insight into the way of formation, what are their specifics, what is required to access a transnational project, as well as the basic characteristics that a project must fulfill in order to be called transnational. Transnational projects represent the cooperation of several partner countries in one region that co-finance a project with the financial assistance of European Union funds (ERDF, IPA). The specifics of transnational projects will be explained through the example of Danube transnational programme.
\end{abstract}

Key words: transnational cooperation, transnational programme, transnational projects.

\section{TRANSNATIONAL PROJECTS}

Nowadays, we can rarely imagine a project where people from different backgrounds and cultures do not participate. One of the specifics of transnational projects lies in the formation and functioning of teams working in different locations aimed at achieving common goal. One of the most widely accepted definitions is: "The transnational project is a temporary, cross-border organizational unit composed of individuals of different nationalities, working in different cultures, business units, and functions, thereby possessing specialised knowledge for solving a common strategic task within multinational corporations." (Marmer, 1998; Schweiger, 1998, as cited in Adenfelt \& Lagerström, 2006). "The transnational project is founded upon the principle of leveraging the knowledge of dispersed units to a temporary unit to enable the creation of new knowledge needed for development of products, processes, and systems for multiple markets." (Demarets, 1997; Osterloh, 2000, as cited in Adenfelt \& Lagerström, 2006).

Transnational projects face the challenge of a diverse group of individuals from different functional parts of organization to work together over a period of time to meet the specific goals of the project. Projects must build confidence and a sense of belonging between project members, as well as respect given deadlines and budget frameworks. Physical distance, cultural differences, language barriers and technological differences in infrastructure are some of the challenges that transnational projects face (Adenfelt \& Lagerström, 2006). There is small chance that members know each other or have met before, so their work, communication and decision-making norms differ (Barczak, 2003; as cited in Adenfelt \& Lagerström, 2006).

Transnational projects develop new approaches, methodologies and practices and demonstrate their feasibility. Proven effects often inspire policy makers to create frameworks that facilitate the implementation of new solutions. This is one of the principal reasons why these projects often reach their full potential years later after the project is completed. Some of the benefits of transnational projects are: Reducing inequality, achieving territorial cohesion, improving the use of scarce resources, addressing challenges beyond borders, building confidence, reinforcing macro-regional strategies, helping authorities improve services, creating attractive results for the regions, driving investment in our future, creating lasting change. 
The specifics of transnational projects (table 1) are reflected in the application procedure, the partners participating in the project, the financing method, the budget approved and the specification of the costs, the management responsible for project management, the project implementation method and the division into work packages as well as the preparation of project teams tasked with working on specific work packages.

Table 1: Comparison of transnational and traditional projects

\begin{tabular}{|c|c|c|}
\hline Area & Transnational projects & Traditional projects \\
\hline Application procedure & A public call for proposals is announced & $\begin{array}{l}\text { None, as projects are approved } \\
\text { based on the needs of the company / } \\
\text { organization }\end{array}$ \\
\hline Partners & $\begin{array}{l}\text { Countries / organizations whose project } \\
\text { proposal has been accepted and is going to be } \\
\text { implemented and which are jointly } \\
\text { participating in the implementation of the } \\
\text { project }\end{array}$ & $\begin{array}{l}\text { The project within the company / } \\
\text { organization is implemented by an } \\
\text { internal project team led by the } \\
\text { project manager }\end{array}$ \\
\hline Financing & $\begin{array}{l}\text { The largest part (up to 85\%) is financed from } \\
\text { the funds of organizations, legal entities or } \\
\text { unions such as the European Union whose } \\
\text { best known funds are IPA and ERDF. } \\
\text { The rest of the funding is provided by the } \\
\text { partners before approving the project } \\
\text { proposal. }\end{array}$ & $\begin{array}{l}\text { From the funds of the company } \\
\text { intended for the project / program; } \\
\text { through loans / loans, corporate } \\
\text { financing, concessions, through the } \\
\text { establishment of a new project } \\
\text { implementation company / special } \\
\text { purpose vehicle. }\end{array}$ \\
\hline Budget & $\begin{array}{l}\text { A detailed budget with all cost items and by } \\
\text { partners is submitted when developing the } \\
\text { project design }\end{array}$ & $\begin{array}{l}\text { The entire sum is approved at the } \\
\text { board meeting with the project } \\
\text { charter }\end{array}$ \\
\hline Management & $\begin{array}{l}\text { Work package leaders report to the project } \\
\text { manager, who reports to the steering } \\
\text { committee. The Committee reports to the } \\
\text { European Commission and the project } \\
\text { auditors }\end{array}$ & $\begin{array}{l}\text { Centralized. The project manager } \\
\text { manages the project }\end{array}$ \\
\hline Realization & $\begin{array}{l}\text { The project is divided into work packages } \\
\text { that need to be implemented. They are } \\
\text { managed by work package leaders with their } \\
\text { teams. At the head of the project is the project } \\
\text { manager with his main team }\end{array}$ & $\begin{array}{l}\text { Project manager with project team } \\
\text { with possible support of external } \\
\text { associates and project sponsor }\end{array}$ \\
\hline Project team & $\begin{array}{l}\text { Each partner country assembles its own team } \\
\text { headed by the leader of the work package } \\
\text { being implemented. The main project team } \\
\text { consists of a project manager with all work } \\
\text { package leaders and experts as well as a } \\
\text { support team. }\end{array}$ & $\begin{array}{l}\text { An internal team within an } \\
\text { organization / company that can be } \\
\text { co-located or distributed. }\end{array}$ \\
\hline
\end{tabular}

\section{TRANSNATIONAL COOPERATION}

Transnational cooperation is an integral part of transnational projects and programs, and involves cooperation between multiple nations i.e. countries in a given geographical area and facilitates joint work between regions from several EU Member States on issues such as communication corridors, flood management, international business, scientific research and developing cost-effective and sustainable markets.

Problems addressed by transnational cooperation programs include (European Commission, 2007):
- Innovations, especially networks of universities, research institutions, SMEs;

- Environment, especially water resources, rivers, lakes, seas;

- Accessibility, including telecommunications, and in particular completion of networks;

- Sustainable urban development, especially polycentric development.

Cross-border and transnational co-operation programmes are called Interreg or territorial co-operation programmes. Within the European Union, transnational cooperation programmes are known as Interreg B. 
Transnational cooperation involves national, regional and local authorities aiming to promote better integration within the Union through the formation of large groups of European regions (Interreg Europe, 2007). Interreg is designed to stimulate cooperation between EU Member States at different levels. One of their main objectives is to reduce the impact of national borders in favor of economic, social and cultural development throughout the European Union.

Transnational programs typically have three sources of funding: IPA funds, the European Regional Development Fund (ERDF) and national budgets of partner countries. IPA funds are a financial aid instrument targeted at candidate countries as well as potential candidates for EU membership. The European Regional Development Fund is an EU fund whose primary purpose is to invest funds from richer regions in the infrastructure of underdeveloped regions.

The European Commission is the main executive body of the European Union, which is supranational and acts outside the competence of the Member States. In addition to the European Parliament and the Council of the European Union, it represents one of the three main institutions governing the Union. The President and members of the Commission are elected by the Member States as they have been previously approved by the European Parliament.

The European Commission (2007) outlines some of the benefits of transnational cooperation:

1. Transnational cooperation helps to reduce and overcome regional disparities and strengthen cohesion in specific regions - by facilitating knowledge sharing, transnational cooperation empowers disadvantaged regions, thereby building capacity and enabling each territory to learn from others, using methods and solutions that are successfully developed or implemented elsewhere in the region;

2. Transnational cooperation builds trust that transcends borders and fosters European integration that aims to make Europe more competitive
3. Financing transnational cooperation is crucial in facilitating the implementation of macro-regional strategies

4. Transnational cooperation projects/ programs address applicable solutions and innovative approaches to solving complex problems and challenges

5. Stronger territorial cohesion transnational partnerships typically explore new terrains and test new approaches to address common, complex and deeply grounded problems. This is how they generate new ideas and build capacity. Participants in transnational projects develop collaborations and a strong sense of shared interests, which often results in framing the problem from a territorial perspective;

6. Enables better use of limited resources.

\section{TRANSNATIONAL PROGRAMME}

Transnational cooperation programmes aim to foster cooperation and regional development through joint problem-solving. In addition, such programmes should encourage the sustainable and innovative development of the area in which they are implemented.

The Danube Transnational Programme (DTP) is a financing instrument for specific scope and an independent decision-making body. It supports the integration of policy in the Danube region in selected fields in accordance with the CPR / ERDF regulations. The strategic vision is "policy integration" in specific areas of activity below EU level and above national level. Transnational projects should influence national, regional and local policies. In order to achieve a greater degree of territorial integration of a very heterogeneous Danube region, the transnational co-operation programme acts as a driver of policy aimed at addressing common challenges and needs arising from specific policy areas. Transnational cooperation is therefore expected to deliver tangible results through the development and practical implementation of policy frameworks, tools and services. To this end, the programme seeks to promote concrete pilot investments. Current needs are related to the problems of how to improve institutional 
frameworks for cooperation, how to improve the quality of policy and its implementation, and how to implement solutions. The success of the implementation of the programme will depend on the targeted selection of the most important interventions and on further increasing the efficiency of administrative procedures and reducing the administrative burden for users (Interreg Danube Transnational Programme, 2018).

\section{PROGRAMME STRUCTURE \\ MANAGEMENT}

The Danube Transnational Program me will use a joint management system to manage, coordinate and monitor its implementation, which means that partner countries and the Commission will be responsible for managing and controlling the program (Figure 1).

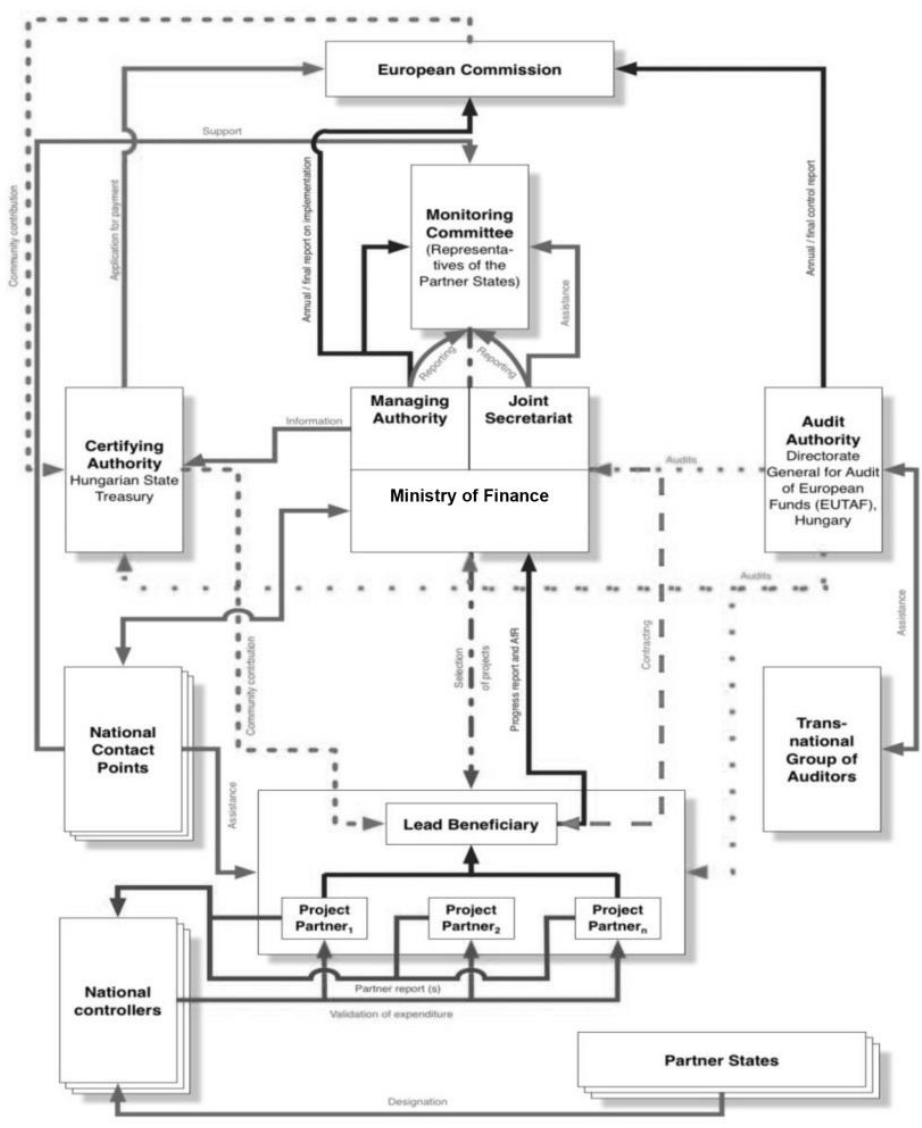

Figure 1: Programme Management Structure (Interreg Danube, 2018)

The governance structure consists of the following bodies (Interreg Danube Transnational Programme 2018):

- The Monitoring Committee (MC), composed of representatives of each participating country, oversees the implementation of the DTP and selects projects to be funded. Its overall task is to ensure the quality and efficiency of the overall programme implementation process. In order to accomplish this task, the Joint Committee will be assisted by the Joint Secretariat (JS).

- The Managing Authority (MA), assisted by the Joint Secretariat hosted by the Ministry of National Economy of Hungary, is responsible for the overall implementation of the programme, carrying out the functions set out in Article 125 of the CPR (Common Provisions Regulation) and Article 23. ETC (European Territorial Cooperation) Regulation. The Joint Secretariat (JC) will 
be the focal point for potential project applicants and lead partners for selected/ongoing operations.

- The Certifying Authority (CA) is responsible for compiling and submitting certified cost statements and payment requests to the European Commission and receiving payments from the European Commission. The CA will use the payments received from the European Commission to compensate the lead partners in accordance with Article 132 of the CPR.

- The Audit Authority (AA) is responsible for ensuring that audits are conducted within the management and control systems and are based on an appropriate sample of operations and annual accounts. The audit body will be assisted by a GoA, composed of representatives from the responsible bodies of each partner country. Each participating country will establish National Contact Points (NCPs), complementary to the transnational activities of the Managing Authority (MA) and the Joint Secretariat (JS) and involving stakeholders from the national level, as well as to contributing to the management of national and transnational programmes and providing guidance and advice to potential applicants and project partners

- Leading Partners (LPs) located in one of the EU DTP Member States will be appointed by all partners participating in the project to carry out the tasks set out in Article 13 of the ETC Regulation. In particular, the Lead Partner will assume responsibility for ensuring the implementation of the entire operation, including arrangements for the recovery of amounts unduly paid.

- Each partner country will designate controllers to ensure that the costs incurred by the project partners are in line with Community and national rules, carrying out verifications within the meaning of Article 23 (4) of the ETC Regulation and Article 125 (5) of the CPR, which covers administrative, financial, technical and physical aspects of the business. Controllers will be appointed in accordance with the national provisions of each partner country. Each country participating in the DTP will be responsible for the verifications carried out in its territory.

\section{CONDITIONS FOR PROJECTS}

The European Union requires that all transnational cooperation programmes must be results-oriented. Such an approach should be reflected in the following (Interereg Project Requirements, 2018):

- Transnational relevance of the subject

- Achieving concrete and measurable output and results, in response to wellidentified transnational challenges affecting the programme area

- Deliver lasting results, such as implementing/integrating investments prepared in a transnational context

- Quality of project partnership

- Efficiency in terms of mobilized resources

- Integrated territorial approach

Projects funded from these funds must be strictly transnational in nature, which means that they must achieve cooperation between different countries and regions. Projects that can be achieved without such cooperation are not considered transnational and will not be funded. Co-operation should be established vertically, between different levels of government and horizontally, between different policy sectors and policy actors and geographically, across administrative borders.

Transnational and territorial relevance is one of the main quality requirements for project financing. Each project must clearly contribute to the chosen programmes specific objective addressing development needs and territorial challenges specific to the programme area shared in the participating regions.

Horizontal principles which are crucial for successful implementation of transnational projects are as follows:

\section{- Sustainable Development}

Sustainable development means that meeting the needs of current generations must not jeopardize the ability of future generations to meet their own needs. When applying for funding, applicants must explain the impact of 
their project on the economic, environmental and social aspects of the targeted region (Interereg Project Requirements, 2018).

Applicants must indicate every possible impact of their project: water, land, air and climate, population and human health, fauna, flora and biodiversity, natural heritage and landscape.

- Equal opportunities and nondiscrimination

Projects must promote equal opportunities for all and prevent any discrimination based on sex, racial or ethnic origin, religion or belief, disability, age or sexual orientation while preparing, designing and implementing transnational cooperation projects. In addition, projects must take into account the special needs of the various target groups that are subject to discrimination and the requirements to ensure accessibility for persons with disabilities. During project selection, it will be checked that the project complies with EU nondiscrimination laws (Interereg Project Requirements, 2018).

\section{- Equality between men and women}

The Danube Transnational Program is committed to gender equality in line with EU policies in this area. Within their activities, projects must ensure equal participation of men and women and avoid any discrimination.

\section{DURABILITY AND PORTABILITY OF PROJECT RESULTS}

In order to ensure territorial impact and longterm benefits after the completion of the project, care must be taken that the objectives achieved during the implementation are lasting, long-term and transferable.

Sustainability is a prerequisite for the durability of output and project results. The following 3 sustainability dimensions must be considered during the project preparation phase (Interereg Project Requirements, 2018):

- Financial sustainability: financing of supporting activities and investments, impact of resources, resources to cover future operating and maintenance costs, etc.
- Institutional sustainability: identifying the structures that will take over actions once the project is completed and strengthening the capacity to transmit the effect.

- Political sustainability: the impact of the project on political choices that will lead to improved legislation, codes of conduct, methods.

In order to achieve the sustainability of project results, it is necessary to adopt a long-term strategic orientation and involve key stakeholders in the planning of project activities from the very beginning. This ensures that the planned outputs have the greatest effect on the right target groups.

Transnational cooperation programs are primarily designed for further territorial integration through enhanced cooperation in specific policy areas. Given the overall size of the budget and limited resources, transnational cooperation programs cannot support large investment interventions and therefore have a large economic impact (Interereg Project Requirements, 2018).

\section{PROJECT PARTNERS}

Establishing a stable and successful partnership is a key prerequisite for applying for funding and then implementing the project. The size of the partnership will reflect a transnational character, but a large partnership will not be the ultimate goal. Excessive partnerships can cause significant organizational, communication and coordination problems and thus be inefficient. Finding the right project partners is a long and difficult process. Applicants are advised to actively involve project partners already in the project development phase and to establish direct and personal relationships with them at that early stage. The partnership must be strategically oriented and tailored to the purpose of the project. The quality of the project depends largely on the integrated composition of its partnership. A good partnership should bring together all the competencies and capacities needed to achieve the project goals and achieve the set results (Interreg Danube Guidance for successful projects, 2018). 
The lead partner is the developer of the entire project. The success of the project is most often linked to the ability and performance of the main partner in the future to cope with the most challenges.

The lead partner, together with the project partners, is responsible for drafting the application form and submitting it to the Managing Authority (MA) / Joint Secretariat (JS). Upon approval of the project, a Subsidy Contract will be concluded between MA / JS and the lead partner. The lead partner, formally the end user of ERDF, IPA and ENI funds, is the only direct link between the project partnership and the programme.

The profile of the potential lead partner should include solid experience in managing EU funded projects as well as experience in managing transnational cooperation projects; Strong institutional capacity, sufficient financial and human resources; Detailed knowledge of program rules; High level of commitment from both the organization and the project management team; Intercultural sensitivity and proactive management team approach; Thematic expertise on the topic of the project; Professional experience in the Danube Region (Interreg Danube Guidance for Successful Projects, 2018).

According to the geographical location criterion, two types of project partners are identified (Interreg Danube Project Requirements, 2018):

1. Directly funded partners: receive direct financial contribution from the Program (by ERDF, IPA and ENI) and bear full responsibility for their budget,

2. Indirectly funded partners not funded directly from the programme budget but supported and sponsored by an ERDF partner who is responsible for their participation in the project.

\section{PROCEDURE FOR SUBMITTING A PROJECT PROPOSAL}

Calls for Proposals are publicly announced on the transnational programme website and consists of two steps. In the first step, applicants are required to submit an Expression of Interest document electronically through the program monitoring system (eMS) stating the project objectives and expected results. The statement of interest in the program contains the logic of the intervention and shows the strategic relevance of the project proposal in terms of contributing to the programmes of specific objectives in accordance with the relevant constraints, where applicable, transnational character and impact, partnership and budget (Interreg Danube Application and Assessment, 2018) .

Once complete and accurate, this document is exclusively submitted electronically via the eMS system. Additional documents will not be accepted and/or considered and after submission no changes to the submitted document are possible. Applicants are notified of the outcome of the assessment process electronically (Interreg Danube Application and Assessment, 2018).

During the selection process, two criteria for deciding whether to apply through (Interreg Danube Application and Assessment, 2018) apply:

1. Eligibility criterion - the verification of the eligibility of the draft project proposal aims to confirm that the proposal has arrived within the stipulated timeframe, that the expression of interest is complete and meets the requirements, that the partnership and projects meet the criteria established at the program level. Failure to meet this criterion results in the rejection of the draft project proposal.

2. Quality criterion - is the basis for evaluating the expression of interest with the aim of bringing projects to a certain ranking for selection.

The draft proposals are then ranked based on the results achieved during the evaluation. The total score will be calculated as the average of the individual points of each question.

- The Commission will recommend project proposals with at least $75 \%$ direct selection.

- Project proposals with between $60 \%$ and $74 \%$ will require additional 
discussions and will be decided by the Steering Committee.

- The Commission will recommend project proposals that have less than $60 \%$ rejection.

The applicants will be informed of the results of the assessment within 10 days of the official approval of the evaluation by the Supervisory Board.

The goals and results must be clearly defined and clearly indicate what changes the project will bring to its current state. The most important aspect of the first step is the proper formulation of the intervention logic. Transnational projects follow results-oriented principles and their implementation brings about change. It is therefore necessary to list in the project intervention logic all the necessary actions that will eventually lead to change.

\section{MANAGEMENT OF PROJECT STRUCTURES}

In defining the project management structure, the principle of lead partner is applied, which means that one institution is designated as lead partner in accordance with the requirements of the program. The lead partner acts as a facilitator between the Program (MA, JS) and the partner. In addition to its responsibilities regarding the implementation of project activities, the lead partner is responsible for establishing and maintaining sound project management and implementation.

Given that the implementation of transnational projects involves the participation of different countries, it is required that each partner country form a project implementation team in its territory to carry out the activities for which they are responsible at their geographical location. The Realization Team consists of two instances: the Main Team and the Support Team comprised of experts from different fields.

Although the size and composition of the project team may vary from project to project, the following are key positions (Interreg Danube Guidance for Successful Projects, 2018):

\section{- $\quad$ Project Manager (PM)}

- Financial Manager (FM)

- Communications Manager (CM)

The lead partner tasks include (Interreg Danube, 2017):

- Organizes partner work

- Oversees implementation of activities

- Provides development and delivery of deliverables and deliverables

- Involves project partners in each activity

- It takes care that activities and costs are at $20 \%$ flexibility

- Ensures quality of results

- Ensures the sustainability and transferability of project results

- Ensures target audience involvement

The tasks of the project partners include (Interreg Danube, 2017):

- Timely implement the activities for which they are responsible

- Contribute to the development and delivery of outputs and outputs

- Report to the lead partner

- Monitor activities and costs with $20 \%$ flexibility

\section{PROJECT COMMUNICATION PLAN}

Good communication between the actors involved in the project realization and implementation is key to its success. Therefore, special attention should be paid to the planning of communication activities to be carried out on the project, as well as to the appropriate staff and budget required. In the application phase, it is expected that the complete communication plan will be available and will show how communication will contribute to the successful implementation of the project.

When defining communication goals, it is necessary to keep in mind that these goals are in sync with the goals of the project and program. All activities envisaged in the project communication strategy must be consistent with the other project activities and be a useful tool for partnership in achieving the main project goals as well as for finally informing in all partner regions about their successes and 
achievements. (Interreg Danube Guidance for Successful Projects, 2018).

\section{FINANCIAL ABILITY AND BUDGET}

Before submitting a project proposal, it is necessary for the lead applicant to do an analysis of the financial capacity of the organization. Such an analysis aims to determine whether the applicant and partner are capable of financing the project within the estimated amount of funding. Since EU funds may be required to cover project costs up to $85 \%$ of the total budget foreseen, it is up to the partners to cover the rest with their own funds. The analysis consists of two parts: making a financial statement and calculating the required coefficients for the final ability assessment. The figures included in the financial statement must relate to the most recent financial statements and balance sheets approved by the board of directors of the organization and submitted to the competent authorities.

\section{COSTS}

Legal framework of transnational projects is very specific and strict, and must be fully respected, otherwise project will be rejected. There are three sets of rules related to the area of project costs: EU regulations and provisions, program rules and national rules.

Costs for which reconciliation should not be used from project and program budgets are ineligible costs and include (Interreg Eligibility of Expenditure, 2018):

- Penalties, fines and costs of litigation, lawsuits and litigation

- Gift costs, other than those not exceeding EUR 50 per gift, which relate to promotion, communication, publicity or information

- Costs associated with fluctuations in foreign exchange rates

- Interest on debt

- Purchase of land and existing buildings

- Value added tax, unless it is recoverable under national VAT law

- Contributions in kind, as defined in Article 69 (1) of Regulation (EU) No 1095/2010. 1303/2013
- Division of project costs among project partners

- Used equipment

Eligibility of expenditure on budget items Regulation (EC) No. 481/2014 sets out the rules regarding the financing of specific items from the budget. These include (Interreg Eligibility of Expenditure, 2018):

- Staff costs

- Office and administrative expenses

- Travel and accommodation costs

- External expertise and service costs

- Expenditure on equipment

- Infrastructure and works

\section{CHANGE MANAGEMENT}

During the project life cycle, changes occur on the project for various reasons. These changes need to be specifically managed to minimize their impact on the project. Project changes will only be accepted in duly justified cases.

Depending on their impact, changes can be minor or major. Although minor changes only require the approval of the MA (MA) / Joint Secretariat (JS) of the PO, major changes, in addition to formal approval by the MA / JS, entail modification of the Subsidy Contract.

\section{CONCLUSION}

The contribution of this paper is to review and systematize the available data on the topic of transnational project management, providing insight into the specifics of the transnational project, as well as the opportunity to better understand its characteristics from both the managerial and the perspective of the potential applicant.

The main characteristic of transnational projects is that they must be result oriented, results achieved concrete, measurable and lasting, to demonstrate efficiency in the use of resources and the quality of the project partnership itself.

One of the key things for participating in transnational projects is the process of applying and fulfilling all the requirements required by the leading partner. 
The transnational programme connects different partner countries in one region through transnational projects. Guided by the same goal and the outputs they receive, they are moving towards the goal of the program and accordingly make a major contribution to strengthening and developing the European Union.

\section{REFERENCES}

Adenfelt, M., \& Lagerström, K. (2006). Enabling knowledge creation and sharing in transnational projects. International journal of project management, 24(3), 191-198.

European Commission, (2007). South-East Europe (SEE) Transnational Co-operation Programme for a European area in transition- Operational Programme. Retrieved 8 11, 2019, from European Union's South-East Europe Programme: www.southeast-europe.net

European Commission- Your guide to policies,information and services. (n.d.). Retrieved 8 29, 2019, from European Commission: https://ec.europa.eu/info/index_en

Interreg Danube Transnational ProgrammeImplementation Manual. (2019, 04 30). Retrieved 08 13, 2019, from Danube Transnational Programme-Documents for Project Implementation: http://www.interreg-danube.eu/relevantdocuments/documents-for-projectimplementation

Interreg Danube Transnational Programme-A Stream of Cooperation. (2018). Retrieved 8 29, 2019, from Interreg Danube: http://www.interreg-danube.eu/
Interreg Danube Transnational ProgrammeApplicants Manual: Application and Assessment. (2018). Retrieved 08 14, 2019, from Danube Transnational Programme: http://www.interregdanube.eu/calls/calls-for-proposals/thirdcall-for-proposals

Interreg Danube Transnational ProgrammeApplicants Pack: Guidance for Successful Projects. (2018). Retrieved 08 13, 2019 , from Danube Transnational Programm: http://www.interreg-

danube.eu/calls/calls-for-proposals/thirdcall-for-proposals

Interreg Danube Transnational ProgrammeApplicants Manual: Danube Transnational Programme. (2018). Retrieved 8 14, 2018, from Danube Transnational Programme: http://www.interreg-

danube.eu/calls/calls-for-proposals/thirdcall-for-proposals

Interreg Danube Transnational ProgrammeApplicants Manual: Eligibility of Expenditure. (2018). Retrieved 08 14, 2019, from Danube Transnational Programme: http://www.interregdanube.eu/calls/calls-for-proposals/thirdcall-for-proposals

Interreg Danube Transnational ProgrammeApplicants Pack: Project Requirements. (2018). Retrieved 8 13, 2019, from Danube Transnational Programme: http://www.interregdanube.eu/calls/calls-for-proposals/thirdcall-for-proposals

What is Interreg Europe? (n.d.). Retrieved 8 29, 2019, from Interreg Europe: https://www.interregeurope.eu 